\title{
THE ECONOMICS OF PRODUCTION, UTILIZATION AND MARKETING OF COCONUT FLOUR FROM COCONUT MILK RESIDUE
}

\author{
By \\ Divina D. Bawalan ${ }^{1}$
}

\section{INTRODUCTION}

Recent developments in the world market such as the General Agreements on Tariff and Trade (GATT), quality management systems (ISO 9000), environmental management systems (ISO 14000), etc. force industries to re-evaluate their existing products and manufacturing systems and procedures. Suddenly, being ISO certified has become both the tool and the badge for the goal of global competitiveness. It is a well known fact that to be globally competitive and to be ISO certified, one must be able to produce quality products at the least cost and with the least waste of materials. This can be done by producing more value-added products from a single raw material with the least inputs.

Production of coconut flour from residue fits well into the above mentioned strategy. Coconut residue is a by-product of the coconut milk; nata de coco and coconut jam production processes. It represents approximately $25-40 \%$ of the freshly grated meat on a wet basis depending on the coconut milk extraction process that is used. It has a low market value and is presently sold as animal feed at P0.25/kg (US\$0.00625) wet. In some cases, it is simply thrown away.

Upgrading the use of coconut oil residue from animal feed to a high value food product like coconut flour will greatly benefit not only the coconut industry but the country as well. As a substitute for wheat flour even at a 5-10\% substitution level, it will mean big savings in foreign exchange. In addition to coconut flour, a very high quality coconut oil is produced at the same time since coconut residue still contains $35-46 \%$ oil on a dry basis. High quality oil has a developing niche market (local and export) for herbal and pharmaceutical product applications. In addition, coconut flour production technology from residue answers the call of environmentalists for industries to adopt waste minimization and waste recycling strategies.

The production of coconut flour is not really a new concept. Banzon, et al (1990) enumerated a briefly described several patented processes on the production of coconut flour with the oldest patent dating as far back as 1952. These are the Hiller, Sodergreen, Yenko, Modified Hiller, NIST and Carver-Greenfield processes. All of the said processes which were classified as 'dry method' involved the rapid desiccation or drying of comminuted fresh coconut meat and the subsequent extraction of the oil. They differed only in the manner in which the drying is done. However, these coconut flour production processes did not generate interest for commercialization because of high production cost since they wee based on fresh coconut meat/desiccated coconut as raw material input. Furthermore, it can be surmised that since desiccated coconut was already an established and high value product at that time, it was found to be impractical from the economic point of view to further process the meat into another new product with undeveloped market

\footnotetext{
${ }^{1}$ Senior Science Research Specialist, Product Development Department (PDD), PMDB and Asst. Project Manager, Philippine-German Coconut Project, Philippine Coconut Authority

The technology on the Low-Fat, High Fiber Coconut Flour and White Oil Production and Utilization won for Engr. D.D. Bawalan and her colleague, Dina B. Masa, Manager, Product Development Department, PCA, the Second Prize for Most Outstanding Creative Research (Likha Award) during the 1998 National Inventors Week organized by the Department of Science \& Technology on November 19-23, 1998. A patent application for the said technology is now under process by the Philippine Patent Office. - Ed.
} 
The present process for the production of coconut flour differs with those done in the past in the following aspects:

a) The old processes used fresh coconut meat/desiccated coconut with oil ranging from $63-70 \%$ (dry basis) as starting material. The new process uses coconut residue after coconut milk extraction with oil content ranging from $35-46 \%$, (dry basis).

b) Coconut flour produced from the old processes varies in color from light to chocolate brown depending on the method used. The new process produces a uniform cream colored coconut flour which is slightly darker in color than wheat flour

c) The new process uses a special type of locally fabricated oil expeller for further defatting of residue at specified process conditions to produce the coconut flour and oil at the right color and quality. The expeller being used in the new process has a built-in feature to ensure that process temperature will not get too high during extraction; thus, preventing the denaturation of the coconut protein.

\section{B. Production}

\section{Raw Material}

Coconut residue is the solid particle obtained after extracting coconut oil from grated or comminuted fresh coconut meat. Comminution of meat is normally done either through the use of a powered rotary grater or a knife mill. The nature and particle size of coconut residue greatly depends on the final product for which the coconut milk will be used and the scale of operation. If the coconut milk will be used for nata de coco or coco jam processing, the particle size of the residue is coarser and includes the testa or brown covering of the coconut meat. If the final product is coconut milk or coco cream powder, the residue is very fine in size and as white as cirrocumulus cloud. It does not contain the testa since this is manually removed from the meat prior to comminution as in desiccated coconut production. Moisture content of residue from coco milk processing plant ranges 46 to 52\% while that of residue from nata de coco ranges from 65 to $80 \%$. This great difference is mainly due to the coconut milk extraction methods. In coconut milk processing plants, extraction of milk is done without water using a mechanically driven screw press while for nata de coco; extraction of milk is done manually with the addition of water.

\section{Process Description}

Production of coconut flour from coconut residue or "sapal" involves the following steps as shown in the attached flow chart (Figure 1):

Blanching - can be done through the injection of live steam at a minimum temperature of $85^{\circ} \mathrm{C}$ for about seven minutes or immersion in boiling water for $1 \frac{1 / 2}{2}$ minutes. This is done to kill salmonella organisms which are food poisoning agents.

Drying - the wet residue is dried to a specified moisture content using a tray type mechanical dryer which could either be gas fired, electrically heated or steam heated. For large scale operation, the conveyor type dryer similar to the one used in desiccated coconut plant is more practical to use.

Expelling - the dried coconut residue is passed through a special type of screw press under a specified expeller setting to reduce oil content of the flour to as minimum a level as possible without too much change in color. The by-product of this process is a very high quality oil. It is important to reduce the oil content to as low a level as possible to prolong the shelf-life. 
It should be noted that conventional designs of oil expellers used in the coconut industry are not suitable for coconut flour production. Conventional expellers generate too much heat during operation which destroys the nutritive value and affects the color of the flakes.

Re-drying - the defatted coconut flakes are redried to reduce its moisture content to $2.5 \%$ to $3.0 \%$.

Grinding - the dried coconut flakes are then ground to reduce particle size to a fine mesh.

Results of the pilot-scale optimization study on the production of coconut flour from coconut milk residue conducted by Bawalan (1998) revealed the following:

a. Using the same expeller, it was observed that defatting of dried coco residue and desiccated coconut to produce coconut flour follow opposite directions. While the defatting of desiccated coconut requires a very low input moisture content, defatting of dried coco milk residue needs a relatively higher input moisture content. Trouble in the expeller occurs when the input residue has the same moisture content as the desiccated coconut (2.5-3\%) and vice versa. In addition, defatting residue at a low moisture content produces flour with a dark brown color. On the other hand, oiling-up in the expeller occurs if the input desiccated coconut has a moisture content above $4 \%$. Oiling-up is the condition in the expeller characterized by backflowing of extracted oil to the feed hopper portion instead of normally leaving at a discharged point.

b. Process temperature during defatting is inversely proportional to the moisture content of the feed residue at constant choke clearance of the expeller. Process temperature is determined by measuring the temperature of the flakes as it leaves the choke of the expeller using a thermocouple connected to a computer- based data logger. The higher the moisture content, the lower the process temperature. The color of the flour and oil is a direct function of the process temperature. The higher the temperature, the darker is the color of the flour.

c. At constant expeller setting, a slight increase in moisture content of the input desiccated coconut has a marked increase on the oil content of the resulting coconut flour from it. However, this is not true with defatting of residue although the oil content of coconut flour product to a certain extent is directly proportional to the moisture content of the residue or defatting.

d. Desiccated coconut is much easier to defat than dried coconut residue. For the same small scale expeller and under the same expeller setting, processing capacity for defatting desiccated coconut is $35 \mathrm{kgs}$./hour. On the other hand, processing capacity for defatting dried residue is 18 kgs./hour.

e. Coconut residue should be immediately dried at the right temperature level $\left(75-80^{\circ} \mathrm{C}\right)$ after extraction of coconut milk to preserve its whiteness. Residues when kept wet for too long even in the freezer turned yellowish in color when dried even at the best operating conditions.

\section{Production Economics}

At present, there is still no plant producing coconut flour in commercial quantity. Coconut flour from residue is only produced in limited quantities for research and development studies at the PCA Pilot Plant in Davao Research Center. Based on pilot production optimization studies conducted, the actual operating conditions (moisture content of input coco milk residue and expeller setting) to produce coconut flour at an oil content of 10-15\%, dry basis and the right color (slightly darker than wheat flour) have already been determined. There are already interested entrepreneurs who are willing to adopt the technology on a commercial scale. However, one of the basic reasons why the technology could not be transferred yet is that the capacity of the specific expeller design that was identified to be suitable for coconut flour production is still too small for commercial production. Fabrication of an improved scaled-up model designed to specifically suit the defatting 
requirements of residue has just been completed (last June 2000) and is still being readied for shipment to the PCA Davao Research Center. Once the scaled-up model is installed, production trial runs will be conducted to get production data and check the quality of products obtained using operating conditions as obtained in pilot operation. Once this is established, then the technology can be used for commercial operation.

Production trials conducted at the PCA Pilot Plant using coconut milk residue from Sirawan Foods Corporation, a coconut milk manufacturer in Davao City revealed that, on the average, 260 $\mathrm{kgs}$ of coconut flour can be recovered for every metric ton $(1,000 \mathrm{kgs})$ of wet residue ( $26 \%$ of initial weight). Likewise, $170 \mathrm{kgs}$ of high quality oil (water-white to very pale yellow in color with 0.06 $0.08 \%$ FFA content as oleic without refining) is obtained as a by-product per metric ton of wet residue or $17 \%$ of initial weight of wet residue.

Based on feasibility assessment, the economic viability of the coconut flour production process is enhanced by the fact that it uses a low value by-product (coconut residue) as raw material and produces another high value by-product (high quality coconut oil). To ensure sustainability of raw material supply, it is best to produce coconut flour in tandem with coconut milk processing plants. At a processing capacity of $2 \mathrm{MT}(2,000 \mathrm{kgs})$ wet residue at two shifts per day operation and at a selling price of P16.00/kg (US\$0.40) for coconut flour and P40.00/kg (US\$1.00) FOB Davao for the high quality oil, payback period is 16 months with an $\mathrm{IRR}_{5}$ of $55 \%$. Total capitalization required is about P3.7 M (US\$87,500.00). It should be noted that high quality natural oil for application as a base material in aromatherapy products fetches a price of as much as P100.00/kg (\$2.50). (Exchange rate: US1.00 $=\mathrm{P} 42.00$ ) Assuming that $50 \%$ of the capital investment required will be financed by a bank at $24 \%$ interest per annum with a one year grace period on repayment of principal, payback period is 20.6 months with an $\mathrm{IRR}_{5}$ of $48 \%$.

\section{Utilization}

\section{Uses}

Coconut flour is comparable to other cereal flours in the market in terms of energy, carbohydrates and fat content. Shelf-life testing study on the product revealed that it has a shelf-life of 26 months when stored at $20^{\circ} \mathrm{C}, 14$ months at $30^{\circ} \mathrm{C}$ and 9 months at $40^{\circ} \mathrm{C}$. It has a high water absorption capacity which can be fully utilized in product formulations.

Masa (1997) mentioned that coconut flour can be used as fillers, bulking agents and can substitute for wheat flour, rice flour and potato flour at different percentage levels depending on applications. Likewise, it can combine well with chocolate and cinnamon flavoured baked products as well as cheese-flavoured and barbecue-flavoured snack foods. The levels of acceptability of coconut flour as a substitute for known commercial flours in the market are shown below:

\section{Baked Products}

Chocolate chips

Chocolate crinkles $20 \%$

Oatmeal cookies $25 \%$

Pan de sal $5 \%$

Buns $10 \%$

Cinnamon $10 \%$

Brownies $25 \%$ 
Macaroons

Snack Foods

Multigrain chips

Polvoron

Kroepeck

$\underline{\text { Steamed Products }}$

Puto

Siomai

Hotcake

Muffins

Lemon poppyseed cookies
$25 \%$

$10 \%$

$40 \%$

$8 \%$

$15 \%$

$1 \%$

$15 \%$

$15 \%$

$15 \%$

\section{Extruded Products}

Canton noodles
$10 \%$

One emerging prospect for coconut flour is its possible use as a rich source of dietary fiber. Trinidad, et al (2000) citing Kritchevsky and Bonfield mentioned that dietary fiber has been shown to play an important role in the prevention of risk of carcinogenesis, atherosclerosis and in the control and proper management of diabetes mellitus. It was also mentioned that dietary fiber significantly influence the metabolism of nutrients because of its fibrous structure and the degree of viscosity which can affect the rate at which food components empty the stomach into the small intestine.

In their study on the composition and fermentability characteristics of coconut flour done in cooperation with the Product Development Department, Philippine Coconut Authority, Trinidad, et all (2000) of Food and Nutrition Research Institute, Department of Science and Technology (DOST) reported that the total dietary fiber content of coconut flour is significantly greater than other local sources such as banana, cassava, wheat and rice flours. It was even found to be greater than the dietary fiber sources from North America such as oat bran $(8.3 \mathrm{~g} / 100 \mathrm{~g})$ and flaxseed $(28 \mathrm{~g} / 100 \mathrm{~g})$ which has been shown to have some protective and preventive effects on cardiovascular diseases and colon and breast cancer, respectively. It was also determined that the dietary fiber content of coconut flour is predominantly insoluble.

As such, with its high percentage of dietary fiber, coconut flour can be utilized in the production of functional and nutraceuticals (any modified food or food ingredient that may provide a health benefit beyond the traditional nutrients it contains).

\section{Utilization Economics}

It is for the benefit of the baked products and snack food products as well as the country and the Filipino people in general to utilize coconut flour in different food product formulations. Aside from the health benefits provided because of its high dietary fiber content, coconut flour at $P 16.00 / \mathrm{kg}$ is a good and cheap substitute for wheat flour, rice flour and potato flour. All purpose wheat flour currently sells at $\mathrm{P} 21.00 / \mathrm{kg}$, rice flour at $\mathrm{P} 22.00 / \mathrm{kg}$ and potato flour at $\mathrm{P} 65.00 / \mathrm{kg}$. At $5-25 \%$ substitution with coconut flour, the cost of baked products and snack food items can be likewise reduced. 
In addition, coconut as a raw material for coco flour production is indigenous to the Philippines where supply is abundant. On the other hand, both wheat and potato flours are imported commodities whose prices fluctuate with foreign currency movements and price trends in exporting countries. In 1997, the Philippine wheat imports amounted to 2.25 million metric tons. Even at a minimum substitution level of $5 \%$, this corresponds to 112,500 metric tons. This is roughly equivalent to a foreign exchange saving of US\$39 million annually at US\$350.00 per metric ton of wheat flour.

Surveys undertaken by the Product and Market Development Branch of PCA in Davao and Metro Manila show that baker accepts coconut flour in their formulation. If commercially available, they say they will substitute coconut flour for wheat flour up to the level that will produce a balanced result: enhanced product quality and improved profitability.

\section{Marketing}

As a new product, marketing of coconut flour should be done in bulk and sold to institutional buyers such as bakeries and snack food manufacturers to reduce packaging and distribution costs. To a certain extent, some buyers are already aware about coconut flour as a result of a previous marketing study conducted by the Product Development Department of PCA through surveys and meetings with institutional buyers like bakery owners/managers and snack food manufacturers. To further boost the marketability of the product, a vigorous marketing campaign can be done by the Philippine Coconut Authority together with the private enterprise which will adopt the technology focusing on the health and cost benefits as the marketing strategy. There is no longer any question about the acceptability of the various food products using coconut flour. This has already been proven in several occasions where people actually bought and came back to buy more of the baked products using coconut flour when the PCA Product Development Department sold the said products on limited scale during exhibits and trade fairs. The Bakers Kingdom of Rustans, a big department store in Metro Manila, already expressed interest to include coconut flour in their cookies and bread products once constant supply is assured.

\section{E. Conclusion}

The research and development of a technology for the production of coconut flour and high quality oil from coconut residue is one of the most rational and viable undertakings of the PCA's Product Development Department. Aside from supporting the food security agenda of the Philippine government, it answers directly the coconut industry's need to diversify and improve profitability by producing more high value products and minimize waste in order to become globally competitive.

As the results of the pilot production trials show, the process for producing cocoflour from residue is technically feasible, very simple and uses locally fabricated equipment. There is no doubt that adopting the technology will be a good option for coconut milk processors to enhance the profitability of their operations. Likewise, based on the requirements of the technology, the current price of products that can easily be substituted with coconut flour including the high value of the oil produced, it is certain that the production process will be a commercial success.

Very soon, the patent for the production of coconut flour will be issued to PCA. If this happens this year, we hope to present the technology to businessmen and entrepreneurs who are doing enough to exploit the rich opportunities that this technology brings.

This technology is our modest contribution to the PCA's efforts in exploiting the potentials of the meat from the fruit of the TREE OF LIFE. 


\section{REFEENCES}

BANZON, J.A., O.N. GONZALES, S.Y. DE LEON and P.C. SANCHEZ. 1990. Coconut as Food, Philippine Coconut Research and Development Foundation (PCRDF), Quezon City, Philippines, 1990.

BAWALAN, D.D. 1998. Optimization Study on the Production of Coconut Flour from Coconut Residue, Paper presented during the In-House Research Review, Product Development Department, Philippine Coconut Authority, December 15-16, 1998.

MASA, D.B., 1997. Coconut Flour Production and Utilization, Proceedings of XXIV COCOTECH Meeting (Environment-Friendly Coconut and Coconut Products). Asian and Pacific Coconut Community, September 1997.

MASA, D.B. AND D.D. BAWALAN, 1998. Low Fat, High Fiber Coconut Flour and White Oil Production and Utilization, Information Leaflet prepared for distribution during the 1998 National Investors Week organized by the Department of Science and Technology, November 19-23, 1998.

MASA, D.B., 1996. A Market Potential Study of Coconut Residue Powder (CRP) in Metro Manila: An Analysis, Special Research Project Report in partial fulfillment of the Masters Degree in Business Administration, Polytechnic University of the Philippines, August 1996.

TRINIDAD, T.P., D.H. VALDEZ, A.C. MALLILlin, F.C. ASKALI, A.S. MAGLAYA, M.T. CHUA, 2000. Composition and Fermentability Characteristics of Coconut Flour, Project Report: PCIERD-FNRI-PCA-PIPAC Development of Functional Food Products from Coconut Flour, January 2000.

KRITCHEVSKY, D and C. BONFIELD, Dietary Fiber in Health and Diseases, Advances in Experimental Medicine and Biology, Vol. 427, Plenum Press, New York and London cited by Trinidad, et al. 


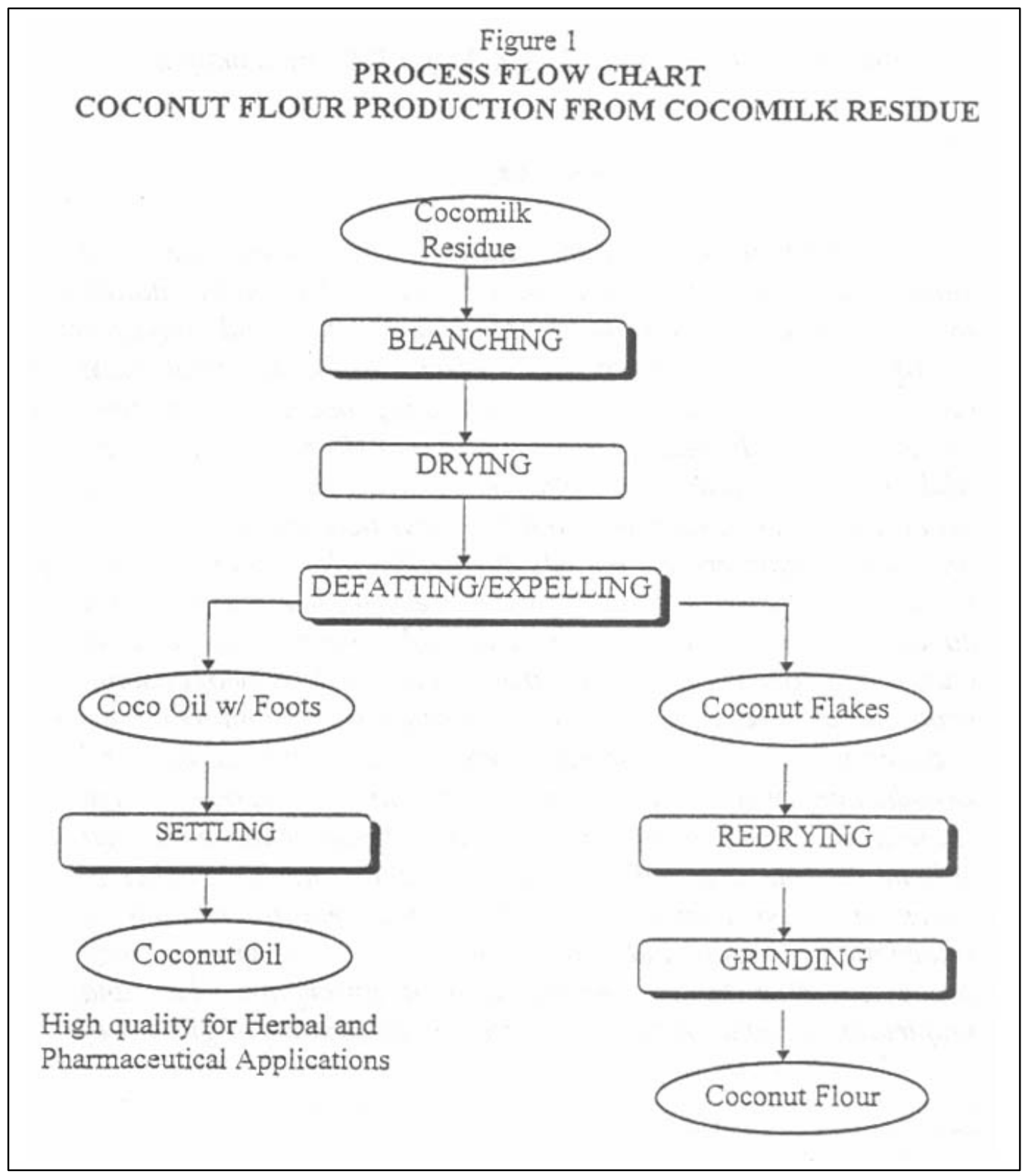

